\title{
Study on the Spread of Chinese Short Video in South Korea Against the Background of Cross-cultural Communication
}

\author{
Yidan Piao ${ }^{1, *}$ \\ ${ }^{1}$ Korean School, Eastern Liaoning University, Dandong, Liaoning, China \\ *Corresponding author. Email: quanjunqi@126.com
}

\begin{abstract}
With the development of Internet technology, network short videos have shown a situation of rapid development. Chinese network short videos are not only going viral in China, but also increasingly becoming popular in Korea. By using data analysis method, literature method, illustration method, investigation method and other research methods, this paper has made an objective analysis of the current situation, reasons and inspirations of the spread of Chinese short videos in Korea and found that the popularity of Chinese short videos in Korea not only play a role in the intercultural communication of Chinese cultures, but provide references for the integration of diversified cultures. And it has definite theoretical and practical significance for Chinese culture "going abroad".
\end{abstract}

Keywords: Short video, Korea, Social culture, Intercultural communication.

\section{INTRODUCTION}

In today's world, economic globalization, cultural diversity, and social informatization are developing in depth, and the interdependence of all countries in the world is deepening. With the great improvement of comprehensive national strength, China is moving towards the center of the world stage, and its relation with the world is changing historically. In the era of mobile internet, short video, as a new way to promote foreign propaganda in China and abroad, has set up a new platform for cross-cultural communication of Chinese culture to "go abroad". As the carrier of spreading Chinese value, explaining Chinese model and sharing Chinese wisdom, short video bears the responsibility and obligation of "going abroad" of Chinese traditional excellent culture and becomes an ideal way to tell Chinese story well to the outside world.

\section{THE BACKGROUND OF CHINESE SHORT VIDEO GOING TO SOUTH KOREA}

\subsection{Humanistic Level}

Short video platform is a new carrier of crosscultural communication, an important path of cultural communication, the new window for the world to understand Chinese culture. By exporting high-quality Chinese cultural content to foreign countries through short video platforms and using audio-visual language to build the Chinese cultural impression, Korean audiences can gradually understand, accept and identify with the cultural values represented by Chinese culture. On the contrary, if the traditional way of communication is followed, even if the Chinese elements "go abroad", it will not be enough to convey the traditional Chinese values, and may even be counterproductive, deepening Koreans' misunderstanding and prejudice against China. General Secretary Xi Jinping pointed out, "When telling the stories of China, we must pay attention 
to dispel the opposing thinking, carry out external communication on the premise of respecting and understanding different values, find the meeting point of Chinese and foreign values, and express the goodwill of foreign exchanges and external communication to the greatest extent. In this way, the benefits of communication can be maximized." Short video, as a powerful carrier of Chinese culture going abroad, helps to show a real, threedimensional and comprehensive China, so that the outside world can better understand China.

\subsection{Technical Level}

The rapid growth of domestic smartphones has given birth to the emergence of a large number of domestic tool applications. Such applications do not require much localized operation, and it is easy to break cultural barriers and pry the Korean market. The functions like one-click special effects, beautifying one's appearance and group photo created by Chinese developers are not only well loved by domestic users, but extremely enjoyed by Korean users. After the exploration of the early tool type mobile phone software, the short video has gained more experience and confidence when it goes abroad, coupled with content consumption with algorithm recommendation as the core has not become popular in South Korea, each player has the opportunity to enter the first camp.

\subsection{Timing Level}

According to 2019 Semi-Annual Report of Short Video published by Quest Mobile, by June 2019, the number of short video users in China has exceeded 820 million. [1] In addition, according to Research Report on Chinese Network Audiovisual Development in 2019 released by China Network Audiovisual Program Service Association, the market scale of the whole video content industry in 2018 was 187.13 billion yuan, up $52.8 \%$ year on year. Among them, the short video market grew the fastest, from 5.53 billion yuan in 2017 to 46.71 billion yuan, up $744.7 \%$ year on year. [2] Despite such a huge development market, the competition of short video industry is extremely fierce, the competition around the user's attention is intensifying, the entire industry has changed from savage growth to intensive cultivation, and the medium and long tail platforms are facing the survival test. With the deepening of the "Belt and Road" policy and the maturity of Internet technology, opening up overseas markets has become an important decision for the development of short video platforms in China in the face of the new situation of the decline of the smartphone entrance dividend. At the same time, the South Korean market's enthusiasm for short video applications continues to rise, which also creates favorable conditions for China's short video to go abroad.

\subsection{Market Level}

According to The Korea Herald reported, a new report released by America Pew Research Center in June 2018 shows that South Korea ranks first in the world in smartphone penetration, with a penetration rate of $94 \%$. [3] At its root, South Korea has high national income and consumption power, as well as it possesses Samsung Electronics and LG Electronics, two influential smartphone manufacturers in the world, with highly developed technology. Based on the high coverage of smartphone penetration, South Korea has become the fifth largest e-commerce market in the world. According to the report released by South Korea Statistics Office in May 2020, the online shopping transaction volume in South Korea has reached 12.72 trillion won (about 74.19 billion yuan), up $13.1 \%$ year on year, of which $68.3 \%$ are conducted by mobile terminals, reaching 8.69 trillion won (about 50.67 billion yuan). [4] South Korea's Cultural Industry Revitalization Institute said in a report recently, the social way of uploading short videos will become the mainstream of the development of South Korea's social networking platform in 2020, as South Korean users spend more time on watching social videos, software products that can be freely created by users may set off a wave of popularity.

\section{CURRENT SITUATION OF CHINESE SHORT VIDEO GOING TO SOUTH KOREA}

\subsection{The Short Video Platforms That Have Successfully Gone Overseas}

The advantages of demographic dividend, relatively similar geographical culture, huge potential user base and highly developed mobile Internet market make South Korea a unique experimental site in the wave of going abroad. Relevant data shows that the current short video applications going to South Korea are Kwai, Xiaokaxiu, Meipai, Volcanic video and Tik Tok and other mainstream players in the domestic market, as well as VivaVideo, VideoShow and 
other just started applications in the domestic market. Among them, the competition for users between Kwai and Tiktok which are two short video giants has opened up a new battleground in South Korea when the domestic market is close to saturation. The overseas edition of Kuaishou "Kwai", which launched in South Korea in May 2017, once jumped to the top of the local list in the downloads, while Tik Tok officially landed in the Korean market in the same year with the name "Tik Tok" and topped the South Korean Google Play video downloaded list in 2018.

\subsection{Representative Short Video Platform Marketing Strategy in Korea}

At home, the Kwai focuses on ordinary people's "extraordinary" and "interesting" and "grounded" in brand tonality. The overseas layout has expanded to South Korea, Japan, Southeast Asia, Europe and South America. The overall tonality is more inclined to "younger" and "fashionable" while overseas style is focused on "little fresh". Kwai has been officially put into operation since May 2017, which has a different development logic from the domestic version. In China, Kwai starts spreading from the third and fourth tier cities, while in South Korea, it was a top-down expansion and Kwai has an independent overseas development team. In terms of function, Kwai is similar to the domestic version, and is mainly used to record and share ordinary people's daily life. And in South Korea it is equipped with the "mouth to mouth" function, by recording video, with the audio track of films and television works, to achieve the effect of performance. This function is very popular with top Korean actresses such as IU, Lin Yun'er, Li Shengjing, Xiu Zhi, and so on. Thanks to the star's personal test and promotion brought by celebrity effect, Kwai became famous overnight in South Korea, and once topped the list of Google play downloads in South Korea. The way of marketing mainly depends on the settlement of Korean famous idol artists and content production, which drive the fashion trend and the upsurge of following stars in Korea. In terms of media cooperation, it has become a popular mainstream application among young people by implanting top variety shows such as Running man and Hyori's Homestay 2.

On the other hand, in August 2017, Tik Tok issued the overseas version of Tik Tok, to its users are distributed in more than 150 countries around the world and hundreds of millions of overseas users. With the features of simple shooting and editing, no ads inserted before the video, the software successfully captured the hearts of young people. After setting off the upsurge in North America, it entered the Korean short video market strongly, and once again caused a short video mutual entertainment boom. According to the data released by Korea Culture Industry Promotion Institute, the downloads of the short video software "Tik Tok" ranked the first in the world in the first half of 2018, far exceeding the downloads of YouTube, Whatsapp, Instagram, Facebook and other softwares.

In terms of functionality, Tik Tok's functionality is similar to that of domestic Tik Tok, in addition to live answers, there is a variety of shooting methods with music to match the content, such as shooting at the same time, it can adjust the shooting speed, add special effects, and insert background music. The marketing mode mainly relies on content production and the settlement of the artists and celebrities of YG, SM and other large Korean brokerage companies, as well as Multi-channel network organizations (MCN) in Korea such as DIA, TV, to expand the application market and improve the popularity. Such as the artists Lee Jong Suk, Nam Joo Hyuk, popular idol groups iKON, Winner, Blackpink and so on of South Korea YG. In terms of media cooperation, there are an investment in the production of musical variety shows and the implantations of products in the programs. To spread the splendid Chinese culture, we should not only have grand postures, but also flexible bodies. Kwai, Tik Tok, and other kinds of short video software have set up a platform of intercultural communication so that domestic cultural disseminators find the export of expression, and also let the Chinese culture lovers across the world get the channel of exchanging and sharing.

\section{ANALYSIS OF THE REASONS WHY CHINESE SHORT VIDEOS BECAME POPULAR IN SOUTH KOREA}

\subsection{Accurate Understanding of Foreign Culture}

To a large extent, the reason why the short video "going abroad" is blocked is due to the lack of understanding of the differences in overseas market culture, geography and national conditions. If an application wants to take root in other places, the most difficult thing is to understand the local users and regional culture and avoid the risks 
caused by different political, ethnic and religious factors, such as the government's difficulties caused by local values, and even the users' abuse. To overcome these difficulties, Chinese short video platforms need not only entrepreneurial enthusiasm, but also tolerance and understanding of these phenomena. Taking Kwai as an example, the reason why it was able to beat all competitors in South Korea is that its understanding of the characteristics of abused amusement of mobile end users in the South Korea and the stronger entertainment atmosphere in South Korean market. It has covered a wide range of people with entertainment functions such as "mouth to mouth" and so on.

\subsection{Eliminating Cultural Barriers Effectively}

Short videos solve not only the limitations of platform, but also the expression problems that have been difficult to overcome for a long time. Every cross-cultural communicator will be worried about how to tell a good Chinese story. Obviously, it is not only the way and the method that influence the effect of cross-cultural communication, but also the idea; not only the language itself, but also how to say the words accepted and loved by foreign audiences. Many Koreans are interested in the classic elements of Chinese culture, such as Hanfu, embroidery, paper cutting, porcelain, traditional Chinese medicine, calligraphy, Peking Opera, martial arts, Go, etc. However, when they came into contact with these Chinese cultural elements in the past, they often only stayed at the level of abstract symbols, knowing one of them but not the other. Compared with graphics and long videos, short videos can make it easy and convenient for users to re-interpret Chinese traditional culture, and can vividly spread Chinese traditional culture to the outside world. By adding short videos to cultural communication and disassembling the moves of Chinese culture one by one, the elements of Chinese culture can be more concrete, the gap of thinking habits can be eliminated, and Korean users can more easily accept Chinese culture.

\subsection{Truly Recording and Accurately Delivering}

The short video is the most efficient form of information recording at present, which has strong universality and can greatly lower the threshold of information exchange and sharing. Through technology empowerment, short video gives everyone the opportunity and ability to record and share their lives fairly. Taking Kwai as an example, its recording and connection functions can show users an interesting and real world. At the same time, users can get their favorite content more accurately, which makes mutual connection and accurate connection possible. In addition, the record itself can improve the sense of happiness, and then make the happiness index of the whole social group increase. Based on this, overseas users, including South Korean users, are used to recording life and displaying skills on Kwai and regard Kwai's short videos as a stage for self-expression.

\subsection{Intelligent Production and Accurate Push}

Short videos use artificial intelligence, algorithm recommendation and other new technologies to create virtual scenes, enrich the cultural space, and provide the public with immersive cultural participation experience. At the same time, personalized push service is developed according to users' preferences, so that users will indulge in the short video world and cannot extricate themselves from it. Taking Tik Tok as an example, with the help of artificial intelligence technology, it realizes the intellectualization, personalization and socialization of content distribution, and makes the short video play more diversified. Innovative play methods based on artificial intelligence technology such as AR stickers, background segmentation and dance machine, provide users with different scene experience and encourage users to create interesting short videos. Once launched, they are widely pursued by Korean users.

\section{INSPIRATIONS FROM THE POPULARITY OF CHINESE SHORT VIDEO IN SOUTH KOREA}

Culture is not only a way of life, but also a kind of spiritual value. Its significance lies in enlightening the soul and strengthening the spirit. As a new way to display culture and a new carrier to record the style of the times, short video has become an effective means to spread Chinese culture and tell Chinese stories to the world in the Internet era, and plays an important role in crosscultural communication. The author summarizes the enlightenment significance brought by this network culture phenomenon to us as the following three points: 


\subsection{Strengthening Industry Self-discipline and Being a Good "Gatekeeper" of Cultural Communication}

The positive significance of short video is not the innovation of the image, but the fact that it is creating a more inclusive and diversified cultural world. It has become a trend of cultural development since the 21 st century to emphasize participation, enhance interaction, encourage sharing and pass happiness. [5] With the full outbreak of video content supported by $5 \mathrm{G}$ technology, the field of short video may present a trend of multi-polarization, more program forms and application scenarios will be nurtured, and the content market will also usher in an era of contention, providing more and better cultural content and services to people, and constantly meet people's multi-level, diversified spiritual and cultural needs. At present, the homogenization of short video content is serious and chaos occurs frequently.

If the platform wants to develop healthily in the fierce competition, good reputation is particularly important. While good reputation comes from highquality products and services. Therefore, the short video platform must take on the social responsibility and strive to become the platform that knows the users best on the track of law. No matter at home or abroad, supervision is the red line that enterprises can not touch. When China's short video platforms go abroad, they should especially make clear of the local regulatory policies and operate reasonably and legally. They need to strengthen self-discipline and self-examination, and always keep policies, regulations and social benefits in mind. In the short run, we can set up barriers or even adopt measures such as banning titles for some content that is not suitable for dissemination. In the long run, we can also establish the necessary content audit mechanisms. By adopting the creator real name registration system and user complaint reporting system, we can enhance the binding force, so that the illegal content can be self-checked, traceable and be fed back, reflect and ensure the self- purifying function of the platform. [6] While the regulators need to strengthen the content supervision, intervene in and resolutely crack down on some illegal acts according to the law, bring the Internet content governance into the orbit of rule of law, purify the market environment and grasp the direction of public opinion by setting rules and clarifying the bottom line. Only in this way can we act as the "gatekeepers" of cultural content and help the short video industry develop steadily.

\subsection{Spreading Positive Energy and Being a "Practitioner" of Civilization Communication}

Short video platform should aim at the changes of market supply and demand in time, strengthen innovation, actively cultivate high-quality content with characteristics, and make it penetrate the daily life of ordinary users. For the content-oriented video industry, whether it is a business platform pursuing traffic economy or a digital infrastructure with publicity as the core, the starting point of all value realization is still content. [7] Content creators, including User Generated Content (UGC), Professional Generated Content (PGC) and MultiChannel Network (MCN), as the main body of the upstream market of the short video industry chain, the quality of the resources provided by them determines the quality of the whole short video industry. In the early stage of the development of short videos, chaos often lies in the short-sighted attitude of eagerness for quick success and instant benefits. In order to get the subsidy and share of the project, some content creators, who are greedy and impetuous, try their best to make a name for themselves by making crude and illegal video content. The above chaos not only confuses the value judgment standard of the network platform but also runs counter to the goal of cultivating new cultural formats and improving the national cultural soft power. Therefore, in the future development process, adhere to the correct content and value orientation will be the iron law of the short video industry. As the "disseminators" of cultural content, short video creators should work hard on the content, show the soul of Chinese culture, take the socialist core values as the basic guidance, combine the characteristics like a short time, fast update, and fine content of short videos to explore creative inspiration around the positive energy of society, produce and promote the positive energy videos close to ordinary people's life, strengthen cultural confidence, and build a culturally strong country.

\subsection{Using Effective Ways to Be the "Leader" of Intercultural Communication}

The world pays great attention to Chinese culture, on the one hand, thanks to the increasing national status, on the other hand, it is due to the more skillful and natural means of cultural 
communication. China's short video applications go abroad, giving the traditional culture a "new sense of vision" and injecting a strong impetus for external communication. When Chinese culture goes abroad, it should be based on its own country and face the world. To improve the soft power of Chinese culture, we need to do the following three points: First of all, we should strive to show the unique charm of Chinese culture. "Only if it belongs to the nation, it belongs to the world." This famous saying, shining with thought and wisdom, dialectically illustrates the relationship between national culture and world culture. To spread Chinese culture to the outside world, we should not only stick to the most original elements of traditional culture but also tell Chinese stories in a language that the world can understand. Only when the spirit remains unchanged even the shape changes, can the original intention of Chinese culture's external communication be realized. Secondly, we should build a platform that is popular with people all over the world, so that the spiritual bearing and value concept of Chinese culture can be spread completely and vividly in our home field. Finally, we should abandon the traditional one-way indoctrination and preaching, and let foreigners widely participate in the recreation of culture. Ji Xianlin once said: "China is a big cultural country in essence, and it is Chinese culture that is most likely to contribute to human civilization." In the past human history, Chinese culture has had a profound impact on the process of world civilization. Now, Chinese "four new inventions (high-speed rail, payment by scanning code, shared-bikes and online shopping)" are full of praise, and the means of cross cultural communication are changing rapidly, boosting cultural dreams to set sail. In the future, it is believed that Chinese short videos will go to more countries and regions, become an excellent carrier that can truly carry the bearing of Chinese culture, and let the cultural content carrying Chinese values go all over the world. Excellent Chinese culture will span time and space, beyond the country, and be full of eternal charm.

\section{CONCLUSION}

The advent of the Internet era has narrowed the distance between countries around the world to just a few inches. It also presents new opportunities for cross-cultural communication. The popularity of Chinese videos in Korea has created a platform for the international communication of Chinese culture, and played a drainage effect of "going abroad" of culture. Despite the current situation, Tiktok and Kwai account for half of the short video market, with the explosion of video content supported by $5 \mathrm{G}$ technology, the short video field may show a multi-polarization trend. The sudden rise of National video and Fun video from Baidu Department is illustrating this point. All kinds of short video platforms with continuous amplification of growth rate and contrarian growth will generate more and more program forms and application scenarios, and innovative practices to meet the individual needs of users will also make the short video content market usher in an era of contention of a hundred schools of thought.

\section{AUTHORS' CONTRIBUTIONS}

This paper is independently completed by Yidan Piao.

\section{REFERENCES}

[1] Quest Mobile: Short video 2019 half-yearly report [DB/OL], (2019-8-6) [2020-7-12] http://www. questmobile. com.cn/research/report-new/58.

[2] China Netcasting Services Association: 2019 China Network Audio Visual Development Research Report [DB/OL], (2019-5-27)[20207-12] https://www.sohu.com/a/316802357_728306.

[3] The Korea Herald: Korea No. 1 worldwide in smartphone ownership, internet penetration [DB/OL], (2018-6-24) [2020-7-12], http://www.koreaherald.com/view.php?ud= 20180624000197\&ACE_SEARCH=1

[4] National Statistical Office (South Korea):Online shopping trends in May 2020 [DB/OL], (2020-7-3)[2020-7-12], http://kostat.go.kr/portal/ korea/kor_nw/1/1/index.board?bmode $=$ read $\&$ $\mathrm{aSeq}=383635$

[5] Zheng Yiyong. Image Representation and Cultural Innovation Significance of Mobile Short Video $[\mathrm{J}]$. Modern Communication (Journal of Communication University of China), 2019(4):29-33.

[6] Li Yang. "Four Points" of Short Video for Health Communication [J]. Chinese journalist, 2018(1):76-77.

[7] $\mathrm{Hu}$ Zhengrong, Li Quan. Return to the realization of content value: the key to the development of short video industry in the era of intelligent omni media $[\mathrm{J}]$. Chinese editor,2020(6):4-8. 